\title{
Impact of tillage and mulching levels on the yield and yield components of wheat
}

\author{
Manzoor Ahmad ${ }^{1 *}$, Zahid Hussain ${ }^{1}$, Jamshad Ali ${ }^{1}$, Mohammad Ilyas ${ }^{2}$, \\ Farzana Begum ${ }^{2}$ and Gulzar Ullah ${ }^{2}$ \\ 1. Department of Agronomy, Bacha Khan University Charsadda, Khyber Pakhtunkhwa Pakistan \\ 2. Department of Horticulture, The University of Agriculture Peshawar- Pakistan \\ *Corresponding author's email: manzoor@aup.edu.pk \\ Citation \\ Manzoor Ahmad, Zahid Hussain, Jamshad Ali, , Mohammad Ilyas, Farzana Begum and Gulzar Ullah. Impact of \\ tillage and mulching levels on the yield and yield components of wheat. Pure and Applied Biology. Vol. 6, Issue 1, \\ pp207-212. http://dx.doi.org/10.19045/bspab.2017.60015
}

\begin{tabular}{llll}
\hline \hline Received: 28/10/2016 & Revised: 30/01/2017 & Accepted: 08/02/2017 & Online First: 11/02/2017
\end{tabular}

\section{Abstract}

A field experiment was conducted during Rabi season 2016 at Bacha Khan Agriculture Research Farm (BARF), Bacha Khan University Charsadda, using wheat variety Pir Sabak 2013. The experiment was laid out in RCB design having two factors i.e. tillage practices (cultivator using 1 time, 3 times, and 5 times) and mulching ( $\mathbf{M}_{0}$-control, $\mathbf{M}_{1}$-wheat straw, and $\mathbf{M}_{2}$-sugarcane bagasse,). Tillage practices were applied to the main plots while mulching to the sub plots having 3 replications with a net plot size of $1.8 \mathrm{~m} \times 5 \mathrm{~m}\left(9 \mathrm{~m}^{2}\right)$ and row to row distance of $30 \mathrm{~cm}$. Data were recorded for days to emergence, plant height, spike length, 1000-grain weight and grain yield. Results of the experiment showed that both tillage practice and mulching has significant effect on almost all the parameters. Tillage showed significant variation for all of the parameters recorded during the course of study except days to emergence. Maximum emergence (199 seedlings $\mathrm{m}^{-2}$ ), were attained by 1 time tillage application where maximum plant height (108 $\mathrm{cm})$, maximum spike length $(12 \mathrm{~cm})$, maximum 1000-grain weight $(45 \mathrm{~g})$ and maximum grain yield (4717) were observed for 5 time tillage application. Similarly mulching application significantly affected all the parameters recorded during the course of experiment except days to emergence. Maximum plant height $(110 \mathrm{~cm})$, spike length $(13 \mathrm{~cm}), 1000$-grain weight $(44 \mathrm{~g})$ and grain yield $\left(5122 \mathrm{~kg} \mathrm{ha}^{-1}\right)$ were recorded for $\mathrm{M}_{1}$ during the experiment. Overall, the combination of five times tillage and wheat mulching $\left(\mathrm{M}_{1}\right)$ provide its superiority in term of yield i.e. $4717 \mathrm{~kg}$ $\mathrm{ha}^{-1}$ and $5122 \mathrm{~kg} \mathrm{ha}^{-1}$, respectively.

Keywords: Wheat; Tillage; Mulching; Growth; Yield

\section{Introduction}

Wheat (Triticum aestivum L.) belongs to the family Poaceae. It is the first grain crop around the world. In Pakistan wheat is used as a staple food because it provides daily dietary needs. Its production is generally for grain purpose, while in countries such as Argentina, Australia, Morocco, Syria and Uruguay, wheat crop is cultivated for grain as well as for fodder purpose and it leads from all other crops regarding area and production [1]. Wheat plays a major role in the world food trade. In Pakistan wheat crop occupied about 8.9 million hectares area with total production of 25.21 million tones and average yield of $2833 \mathrm{~kg} \mathrm{ha}^{-1}$. While in Khyber Pakhtunkhwa, it occupied 0.72 million hectares area, the production was 
1.15 million tones and the average yield was $1595 \mathrm{~kg} \mathrm{ha}^{-1}$ during 2010-11 [2]. It is an important food crop for Barani areas as well as for irrigated areas and plays a very important role in meeting the food requirements of both urban and rural population. It contributes 14.4 percent to agriculture and 3 percent to the gross domestic production (GDP) of Pakistan. Pakistan ranks in the top ten highly producing countries of wheat [3]. It is grown mainly under irrigated conditions and its water requirement ranges from 20-21 inches per acre.

Tillage not only improves soil tilth but also reduces soil compaction, risk of weeds, soilborne diseases [4] and enhances soil temperature, aeration, incorporation and decomposition of crop residues [5]. However, continuous ploughing at same depth causes formation of subsurface hardpan [6] which reduces nutrient and water use efficiencies and root growth [7]. Deep tillage is done to overcome the problem of soil compaction. Deep tillage has more moisture content at $50-100 \mathrm{~cm}$ soil depth and reduces at $0-50 \mathrm{~cm}$; however, deep ploughing is expensive in terms of fuel and time. The conventional tillage is being practiced all over Pakistan which transforms physical, chemical, biological and electrochemical properties of soil that in turn conserves soil moisture [8]. Zero tillage technology has been adopted to prevent late sowing of wheat. It facilitates sowing of wheat at proper time and good crop establishment. It also saves the cost of water and preparation of seedbed up to $30 \%$ [9]. Zero-tillage technology enhances the wheat yield as compared to the other tillage practices and facilitate less use of machinery and hence energy can be saved through less consumption of fuel [10]. Use of intensive and unnecessary conventional tillage practices is often harmful to soil. Therefore, currently there is a significant interest and emphasis on the shift to the reduced and zero-tillage for increasing water use efficiency of summer crops, controlling erosion process and increasing crop production [11].

Mulches play a vital role for conserving the moisture in the soil profile for the success of wheat production, which totally depends on the precipitation received before and during crop growth period. Mulches reduce the evaporation losses. The practice of mulching has been widely used as a management tool in many parts of the world [12]. However, the effect varies with soils, climate, and kind of mulch material used and the rate of application. The surface mulch favorably influences the soil moisture regime by controlling evaporation from the soil surface, improves infiltration, soil water retention, decreases bulk density and facilitates condensation of soil water at night due to temperature [12]. Variation of the soil microclimate by mulching favors seedling emergence and suppress weed population $[13,14]$. Many researchers [15] carried out studies to determine the effect of different mulches on the wheat production. These studies showed that the application of mulches increased grain yield of wheat in comparison with un-mulched wheat. [16] found that wheat straw mulch reduced evaporation by 50 percent under winter wheat and saved about $80 \mathrm{~mm}$ water during wheat growth season. Mulch increased the soil moisture in root zone and significantly decreased soil temperature, which was suitable environment for seedling establishment and growth of wheat [14]. Moreover, plastic mulch enhanced the crop yield by changing soil properties, increased nutrient and water use efficiency and soil moisture [17]. Keeping in view the increasing demand of wheat, the present study was therefore conducted to determine the effects of different tillage practices and 
mulching types on growth, yield and yield components of wheat.

\section{Materials and methods}

A field experiment was conducted to find out the impact of tillage practices and mulching on the yield and yield components of wheat. The experiment was conducted at Bacha Khan Agriculture Research farm (BARF) Charsadda. The experiment was laid out in factorial experiment with randomized complete block design having 9 treatments and 3 replications. Three tillage practices (Cultivator using 1 time, 3 times and 5 times followed by planking) and three mulching levels (control, wheat straw and sugarcane bagasse) were used. A net plot size of $1.8 \mathrm{~m} \times 5 \mathrm{~m}\left(9 \mathrm{~m}^{2}\right)$ was used having row to row distance of $30 \mathrm{~cm}$. Data was collected on the following parameters. Days to emergence, Plant height, Spike length,1000-grain weight and Grain yield.

\section{Result and discussion}

Days to emergence

Tillage, mulching and their combination showed non-significant effect on days to emergence of wheat (Table 1). However, plot ploughed by five times tillage shows more days to emergence 12 as compared to cultivator 1 times and 3 times tillage. Similarly more days (12) to emergence were taken by $\mathrm{M}_{0}$ and $\mathrm{M}_{2}$ as compared to $\mathrm{M}_{1}$. On days to emergence tillage and mulching showed non-significant effect this might be due the fact that at germination stage, the seedlings are mostly depends on stored food rather than on external environment. The result are in line with $[18,19]$ who reported that germination mostly depends on reserved food.

Table 1. Days to emergence as effected by tillage practices and mulching

\begin{tabular}{|l|c|l|l|l|}
\hline \multirow{2}{*}{ Tillage practices } & \multicolumn{3}{|c|}{ Mulching $\left(\mathbf{k g ~ h a}^{-\mathbf{1}}\right)$} & \multirow{2}{*}{ Mean } \\
\cline { 2 - 5 } & 11 & $\mathbf{M 1}$ & $\mathbf{M 2}$ & \\
\hline 1 time & 11 & 11 & 12 & 11 \\
\hline 3 times & 11 & 12 & 12 & 11 \\
\hline 5 times & 11 & 12 & 12 & 12 \\
\hline \multicolumn{1}{|c|}{ Mean } & \multicolumn{2}{|c|}{ M0 } &
\end{tabular}

\section{Plant height}

Plant height as affected by various levels of tillage and mulching data are presented in (Table 2). Statistical analysis of the data revealed that tillage's and mulching had significant effect on plant height while the interaction had non-significant effect. Maximum plant height $(108 \mathrm{~cm})$ when plot treated with tillage cultivator 1 times and minimum $96 \mathrm{~cm}$ was observed. Among mulching maximum plant height $110 \mathrm{~cm}$ were recorded with wheat straw mulching as compared to other mulching practices. Similar result was reported by [20]. Maximum plant height was recorded in plots where wheat straw was used as mulch, as compared to sugar cane and no mulch. Similar finding was observed by [21].

Table 2. Plant height as effected by tillage's and mulching

\begin{tabular}{|l|l|l|l|l|}
\hline \multirow{2}{*}{$\begin{array}{l}\text { Tillage's } \\
\text { cultivator times) }\end{array}$} & \multicolumn{3}{|c|}{ Mulching $\left(\mathbf{k g ~ h a}^{-1}\right)$} & \multirow{2}{*}{ Mean } \\
\cline { 2 - 5 } & M0 & M1 & M2 & \\
\hline 1 time & 85 & 107 & 97 & $96 \mathrm{c}$ \\
\hline 5 times & 89 & 109 & 99 & $99 \mathrm{~b}$ \\
\hline Mean & 103 & 113 & 106 & $108 \mathrm{a}$ \\
\hline
\end{tabular}

LSD at $\mathrm{P}<0.05$ for tillage's $=6.29, \mathrm{LSD}$ at $\mathrm{P}<0.05$ for mulching $=6.29$ 


\section{Spike length}

Spike length as affected by tillage's and mulching data are presented in (Table 3). Statistical analysis of the data revealed that tillage's and mulching as well as T x M had significant effect on spike length of wheat. Lengthy spikes $(12 \mathrm{~cm})$ were produced when plot ploughed with cultivator 5 time as compared to one time and three time (10 $\mathrm{cm})$ and $(11 \mathrm{~cm})$. The results are in line with
[22] who reported that increased in tillage intensities, increase spike length. Mulch material had significant effect on spike length. Maximum $(13 \mathrm{~cm})$ spike length was observed when wheat straw mulch was used as compared to sugar cane mulch. While no mulch and $\mathrm{T} \times \mathrm{M}$ result maximum $(11 \mathrm{~cm})$ and minimum $(7 \mathrm{~cm})$ maintained. These results are in agreement with the investigations of [23].

Table 3. Spike length as effected by tillage's and mulching

\begin{tabular}{|l|l|l|l|l|}
\hline \multirow{2}{*}{$\begin{array}{l}\text { Tillage's } \\
\text { (cultivator times) }\end{array}$} & \multicolumn{3}{|c|}{ Mulching $\left(\mathbf{k g ~ h a}^{-1}\right)$} & Mean \\
\cline { 2 - 5 } & M0 & M1 & M2 & \\
\hline 1 time & 7 & 13 & 11 & $10 \mathrm{c}$ \\
\hline times & 10 & 13 & 11 & $11 \mathrm{~b}$ \\
\hline 5 times & 11 & 13 & 11 & $12 \mathrm{a}$ \\
\hline Mean & $10 \mathrm{c}$ & $13 \mathrm{a}$ & $11 \mathrm{~b}$ & \\
\hline
\end{tabular}

LSD at $\mathrm{P}<0.05$ for tillage's $=0.86, \mathrm{LSD}$ at $\mathrm{P}<0.05$ for mulching $=0.86, \mathrm{LSD}$ at $\mathrm{P}<0.05$ for $\mathrm{T} \times \mathrm{M}=1.49$

\section{0-grain weight}

1000-grain weights as affected by tillage's and mulching data are presented in (Table 4). Statistical analysis of the data revealed that tillage's and mulching had significant effect on thousand grain weight while $\mathrm{T} \times \mathrm{M}$ had non-significant effect. Maximum thousand grain weight (45 g) was recorded when plot ploughed by cultivator five time and cultivator one time resulted minimum thousand grain weight $(35 \mathrm{~g})$. The findings are in agreement with the result of [24], who observed that the 1000-grains weight significantly influenced by tillage practices. on other hand wheat mulch attained maximum thousand grain weight ( $44 \mathrm{~g}$ ) than sugar cane mulch (39 g) while no mulch resulted minimum (36 g) thousand grain weight. The results are in agreement with that of [24].

Table 4. 1000-grain weight as effected by tillage's and mulching

\begin{tabular}{|l|l|l|l|l|}
\hline \multirow{2}{*}{$\begin{array}{l}\text { Tillage's } \\
\text { cultivator times) }\end{array}$} & \multicolumn{3}{|c|}{ Mulching $\left(\mathbf{k g ~ h a}^{-1}\right)$} & \multirow{2}{*}{ Mean } \\
\cline { 2 - 5 } & M0 & M1 & M2 & \\
\hline 1 time & 30 & 40 & 35 & $35 \mathrm{c}$ \\
\hline 3 times & 35 & 43 & 40 & $39 \mathrm{~b}$ \\
\hline 5 times & 43 & 49 & 42 & $45 \mathrm{a}$ \\
\hline Mean & $36 \mathrm{c}$ & $44 \mathrm{a}$ & $39 \mathrm{~b}$ & \\
\hline
\end{tabular}

LSD at $\mathrm{P}<0.05$ for tillage's $=2.45$, LSD at $\mathrm{P}<0.05$ for mulching $=2.45$

\section{Grain Yield}

Grain Yield as affected by tillage's and mulch are presented in (Table. 5). It was observed from the statistical analysis of the data that grain yield significantly affected by tillage's and mulching however the combination of $\mathrm{T} \times \mathrm{M}$ was found nonsignificant. It was examined from the analysis that wheat mulch performs better than sugar cane mulch and resulted more grain yield $\left(5122 \mathrm{~kg} \mathrm{ha}^{-1}\right)$ than $\left(4319 \mathrm{~kg} \mathrm{ha}^{-}\right.$ $\left.{ }^{1}\right)$ of sugar cane. The findings are in 
agreement with the result of [25] who reported the significant effects of mulching on yield of wheat. Similarly cultivator five times tillage's produced maximum grain yield (4717 $\left.\mathrm{kg} \mathrm{ha}^{-1}\right)$ as compare to one time (4303 $\mathrm{kg} \mathrm{ha}^{-1}$ ) and three times (4559 $\mathrm{kg} \mathrm{ha}^{-1}$ ) tillage's followed by planking. In case of $\mathrm{T}$ $\mathrm{x} M$ combination with cultivator five time tillage's produced maximum (5383 $\left.\mathrm{kg} \mathrm{ha}^{-1}\right)$ grain yield. Similar results were reported by [25].

Table 5. Grain yield as effected by tillage's and mulching

\begin{tabular}{|l|l|l|l|l|}
\hline \multirow{2}{*}{$\begin{array}{l}\text { Tillage's } \\
\text { cultivator times) }\end{array}$} & \multicolumn{3}{|c|}{ Mulching $\left(\mathbf{k g ~ h a}^{-\mathbf{1}}\right)$} & \multirow{2}{*}{ Mean } \\
\cline { 2 - 5 } 1 time & M0 & M1 & M2 & \\
\hline 3 times & 3990 & 4800 & 4120 & $4303 \mathrm{c}$ \\
\hline 5 times & 4207 & 5181 & 4289 & $4559 \mathrm{~b}$ \\
\hline Mean & 4220 & 5383 & 4546 & $4717 \mathrm{a}$ \\
\hline
\end{tabular}

LSD at $\mathrm{P}<0.05$ for tillage's $=153.6, \mathrm{LSD}$ at $\mathrm{P}<0.05$ for mulching $=153.6$

Means followed by similar letters are significantly similar at $\mathrm{p} \leq 0.05$ using LSD

\section{Conclusions and recommendations}

Based on results, it is concluded that Five times tillage followed by planking performed better and recommended for more grain yield in wheat. Wheat mulch performed better and is recommended for higher grain yield in wheat in the near future.

\section{Authors' contributions}

Conceived and designed the experiments: $\mathrm{M}$ Ahmad, Performed the experiments: J Ali, Analyzed the data: G Ullah, Contributed reagents/ materials/ analysis tools: $\mathrm{Z}$ Hussain, Wrote the paper: $M$ Ilyas \& F Begum.

\section{References}

1. Din S, Ramzan M, Khan R, Rahman M, Haroon M, Khan TA \& Samad A (2013). Impact of tillage and mulching practices on weed biomass and yield components of maize under rainfed condition. Pak J Weed Sci Res 19(2): 201-208.

2. Anon (2010-11). Economic Survey of Pakistan. Ministry of Food, Agriculture and Livestock, Economic Wing, Govt. of Pakistan. Islamabad.

3. GOP, Economic survey of Pakistan. Finance and Economic Affairs Division, Islamabad, 2012
4. Boydas MG \& Turgut N (2007). Effect of tillage implements and operating speeds on soil physical properties and wheat emergence. Turk. J Agric 31: 399-412.

5. Crovetto CC (2006). No-tillage: The relationship between no tillage, crop residues, plants and soil nutrition. Therma Impresores S.A, Hualpén, Chile.

6. Alakukku L, Weisskopf P, Chamen, WCT, Tijink FG \& Linden JP (2003). Prevention strategies for field trafficinduced subsoil compaction: a review. Part 1. Machine/soil interactions. Soil Till Res 73: 145-160.

7. Ishaq M, Hassan A, Saeed M, Ibrahim M \& Lal R (2001a). Subsoil compaction effects oncrops in Punjab, Pakistan: I. Soil physical properties and crop yield. Soil Till Res 59: 57-65.

8. Jin H, Hongwen L, Rasaily RG, Qingjie W, Guohua C, Yanbo S, Xiaodong Q \& Lijin L (2011).Soil properties and crop yields after 11 years of no tillage farming in wheat maize cropping system in North China Plain. Soil and Tillage Research 113: 4854.

9. Aslam M, Majid A \& Gill MA (1999). Zero tillage wheat production technology prospects and threats, Science and 
Technology Development International Journal Vol.1: 15-19.

10. Grey RS, Taylor JS \& Brown WJ (1996). Economic factors contributing to the adoption of reduced tillage technologies in central Saskatchewan, Canadian Journal of Plant Sciences Vol.76: 661-668.

11. Dawelbeit MI \& Babiker EA (1997). Effect of tillage and sowing method on growth and yield of wheat, Soil and Tillage Research Vol.42: 127-32,

12. Yang Y, Xiao-jing L, Li W \& Li C (2006). Effect of different mulching materials on winter wheat production in desalinized soil in heiloggang region of north China. J Zhejiang Univ Sci 7(11): 858-867.

13. Singh IP (1994). Effect of organic mulches on weed population, yield and percentage of sunscald fruits of summer tomato (Lycopersicon esculentum Mill) variety Pant Bahar. Recent Horti 1 (1): 80-83.

14. Lalitha BS, Nagaraj KH \& Anard TN (2001). Effect of soil solarization on weed dynamics and yield of groundnuttomato sequence. Mysore J Agric Sci 35(3): 226-231

15. Xie Z, Wang Y \& Li F (2005). Effect of plastic mulching on soil water use and spring wheat yield in arid region of northwest China Agricultural Water Management 75: 71-83.

16. Wang H, Zhang L, Dawes WR \& Liu C (2001). Improving water use efficiency of irrigated crops in the north China plain-measurements and modeling. Agric Water Manage 48(2): 151-167.

17. Feng-Min L, Wang J, Jin-Zhang X \& Hui-Lian X (2004). Productivity and soil response toplastic film mulching durations for spring wheat on entisols in the semiarid Loess Plateauof China. Soil Till Res 78(1): 920.
18. Shrivastava BK, Singh MP \& Jain SK (1992). Effect of spacing and nitrogen levels on growth, yield and quality of seed crops of radish. Seed Res 20: 85-7.

19. Tigre W, Worku W \& Haile W (2014). Effects of nitrogen and phosphorus fertilizer levels on growth and development of barley (Hordeum vulgare L.) at Bore District, Southern Oromia, and Ethiopia. American Journal of Life Sciences 2(5): 260-266.

20. Imran A, Shafi J, Akbar N, Ahmad W, Ali M \& Tariq S (2013). Response of Wheat (Triticum aestivum) Cultivars to Different Tillage Practices Grown under Rice-wheat Cropping System. Universal Journal of plant science 1(4): 125-131.

21. Shafiq M, Amin MR, Ikram MZ \& Sandhu GR (1994). Effect of fertilizer and mulches on wheat growth and yield under rainfed conditions. J Agric Res 32(92): 165-171.

22. Ehsanullah, Khan S, Qamar R, Ghaffar A \& Mustafa G (2013). Impact of tillage and mulch on water conservation in wheat (Triticum aestivum L.) under rice-wheat cropping system. J Agric Res 51(3).

23. Ahmed NM \& Rashid AG (1996). Fertilizer and their use in Pakistan, NFDC. Publication, No.4/96,2nd Ed, Islamabad.

24. Ahmed ZI, Ansar M, Iqbal M \& Minhas NM (2007). Effect of planting geometry and mulching on moisture conservation, weed control and wheat growth under rainfed conditions Pak J Bot 39(4): 1189- 1195.

25. Depar N, Shah JA \& Memon MY (2014). Effect of organic mulching on soil moisture conservation and yield of wheat. Pak J Agri Agril Eng, Vet Sci 30 (1): 54-66. 